ISSN Print : 1411 - 951 X, ISSN Online : 20503-1716

Jurnal Ergonomi Indonesia

(The Indonesian Journal of Ergonomic)

\title{
ANALISIS BEBAN KERJA PETANI PADA PENGOLAHAN LAHAN STROBERI DI KABUPATEN TABANAN
}

\author{
M.Yusuf ${ }^{1}$, Nyoman Adiputra ${ }^{2}$, I Dewa Putu Sutjana ${ }^{3}$, Ketut Tirtayasa ${ }^{4}$ \\ ${ }^{1}$ Mahasiswa Program Doktor, Pasca Sarjana, Udayana University \\ ${ }^{1}$ Staf Pengajar Politeknik Negeri Bali. \\ 2,3,4 Bagian Faal, Fakultas Kedokteran Universitas Udayana
}

Email : yusuf@pnb.ac.id

\begin{abstract}
Abstrak
Di Kabupaten Tabanan terdapat daerah penghasil stroberi yaitu daerah Bedugul. Bedugul merupakan daerah wisata yang terkenal bukan hanya di Bali atau Indonesia, bahkan dikenal di dunia. Dalam proses penanaman stroberi, petani mengolah lahan dengan cara membuat bedeng terlebih dahulu, menambahkan pupuk, melapisi bedeng dengan plastik mulsa, dan membuat lubang pada plastik mulsa tersebut. terdapat permasalahan dalam proses pengolahan lahan stroberi ini, seperti terjadinya keluhan otot skeletal dan kelelahan secara umum. Penelitian ini dilakukan secara observasional terhadap 12 petani stroberi yang ada di Bedugul Kabupaten Tabanan. Beban kerja ditentukan dari nadi kerja yang dihitung dengan metode 10 denyut pada arteri radialis dengan stop watch. Suhu lingkungan dan kelembaban diukur dengan sling Psychrometer. Kecepatan angin diukur menggunakan Anemometer. Suhu panas radiasi matahari diukur dengan termometer bola. Kelelahan secara umum di prediksi dari koesioner 30 item kelelahan dengan empat skala Likert, dan keluhan otot skeletal diprediksi dengan kosioner Nordic Body Map. ECPT (extra calorie due to peripheral temperature) dan ECPM (extra calorie due to peripheral metabolism) dihitung berdasarkan denyut nadi pemulihan petani. Hasil penelitian ini menyimpulkan bahwa : (1) Beban kerja petani stroberi kategori beban kerja berat, (2) Terdapat perbedaan yang signifikan pada skor keluhan subjektif petani (keluhan otot skeletal dan kelelahan secara umum) sebelum dan sesudah kerja, (3) Nilai ECPM lebih besar dari ECPT sehingga upaya-upaya untuk memperbaiki pelaksanaan aktivitas petani stroberi dapat diarahkan pada hal-hal yang berhubungan dengan pelaksanaan kerja (task), (4) Skor analisis rula diperoleh nilai grand score 7, hal ini direkomendasikan untuk segera dilakukan perbaikan. Oleh karena itu disarankan agar segera dilakukan perbaikan pada sistem kerja petani stroberi tersebut.
\end{abstract}

Kata Kunci : Beban Kerja, keluhan otot skeletal, Kelelahan secara umum, ECPT, ECPM.

\section{FARMERS WORKLOAD ANALYSIS ON PROCESSING STROWBERRY FIELD IN TABANAN REGENCY}

\begin{abstract}
Bedugul is a village in Tabanan regency that produce strawberry. Bedugul is famous tourist area not only in Bali or Indonesia, are even known in the world. . In the process of planting strawberries, farmers cultivate land by making raised beds (bedeng) beforehand, add fertilizer, coat beds with mulch, and make a hole in the plastic mulch. there are problems in the processing of these strawberry fields, such as the musculoskeletal disorder and general fatigue. This research was conducted observational against 12 strawberry farmers in Bedugul Tabanan regency. The workload is predicted by calculated the pulse that measured by ten
\end{abstract}


pulse methode in artery radialis use a stopwatch. Ambient temperature and humidity are measured with a sling psychrometer. Wind speed is measured using the anemometer. Temperature heat of solar radiation measured with a thermometer bulb. General fatigue predicted by 30 item questioners about fatigue with 4 Likert scale. Musculoskeletal disorders predicted by Nordic Body Map. ECPT (extra calorie due to peripheral temperature) and ECPM (extra calorie due to peripheral metabolism) is calculated based on the pulse restore of the farmers. The results of this research concluded that: (1) Workload strawberry farmers categories of heavy workload, (2) There are significant differences in the score of subjective disorder of farmers (musculoskeletal disorder and general fatigue) before and after work, (3) The value of ECPM higher than ECPT so that to improve the activity of the farmers can be done through the task of strawberry farmers (4) score RULA analysis values obtained grand score of 7 , that is mean investigation and change are required immediately. It is therefore recommended to immediate improvement in the work of the strawberry farmers.

Keywords : workload, musculoskeletal disorder, general fatigue, ECPT, ECPM.

\section{Pendahuluan}

Stroberi merupakan salah satu tanaman hortikultura yang banyak ditemui di daerah agrowisata seperti di Bedugul Bali, Batu Malang, dan Ciwidey Jawa barat. Buah stroberi disukai banyak orang, terutama karena aromanya yang khas, warna merah cerah yang kaya akan pigmen antosianin yang mengandung antioksidan tinggi dan juga senyawa-senyawa lain seperti serat, vitamin $C$, potasain dan asam ellagic, dan dikonsumsi dalam jumlah besar baik dimakan langsung atau dalam makanan olahan seperti manisan, jus buah, pie, es krim, milk shake, dan sebagainya. Stroberi merupakan salah satu komoditas yang memiliki nilai ekonomi tinggi dan pangsa pasar yang baik dengan jumlah produksi untuk tingkat dunia sebesar 3.198.689 ton pertahuan (Hui, 2006). Stroberi ini dapat tumbuh dan berproduksi dengan baik pada kondisi iklim seperti di Indonesia (Budiman dan Sastrawati, 2008).

Di Kabupaten Tabanan terdapat daerah penghasil stroberi yaitu daerah Bedugul. Bedugul merupakan daerah wisata yang terkenal bukan hanya di Bali atau Indonesia, bahkan dikenal di dunia. Bedugul terletak di Desa Candikuning II, Kecamatan Baturiti, Kabupaten Tabanan, Bali. Di daerah Bedugul, ada wisata danau, kebun raya, perkebunan dan wisata pertanian (agrowisata). $80 \%$ penduduk Bedugul adalah petani dengan luas pertanian mencapai 600 Hektar (Monografi, 2011). Sebagian besar petani tersebut bercocok tanam pada jenis tanaman hortikultura dari jenis tanaman sayur, buah, hingga bunga. Salah satu produk pertanian yang terkenal di Bedugul adalah stroberi yang sudah dikembangkan sejak tahun 1986 (Arimbawa, 2012).

Dalam proses penanaman stroberi, petani mengolah lahan dengan cara membuat bedeng terlebih dahulu. Pada bedeng ini diberi campuran pupuk kemudian ditutup dengan plastik mulsa. Setelah ditutup dengan plastik mulsa kemudian dibuat lubang pada plastik mulsa ini. Pembuatan bedeng dan pembuatan lubang pada plastik mulsa dilakukan dengan sikap kerja membungkuk. Pembuatan bedeng dilakukan menggunakan cangkul, sedangkan pembuatan lubang pada plastik mulsa dilakukan menggunakan alat berupa kaleng yang diisi bara api kemudian dikasih gagang dan ditempelkan ke plastik mulsa sehingga plastik berlubang (meleleh pada bagian bawah kaleng).

Pembuatan lubang ini dilakukan dengan cara membungkuk dan setiap kali bara api mulai dingin, petani harus ke pinggir sawah untuk membuat bara baru atau memanasi arang yang ada dalam 
kaleng. pekerjaan ini dilakukan pada semua bedeng yang ditutup plastik mulsa, sehingga menjadi permasalahan tersendiri bagi petani yang di bedugul, terlebih lagi lahan yang dikerjakan cukup luas. Sikap kerja membungkuk dalam waktu yang lama merupakan sikap kerja yang tidak alamiah (tidak normal). Sikap kerja tidak alamiah akan menyebabkan kekurangserasian antara manusia dan stasiun kerjanya, sehingga menimbulkan hal-hal yang tidak diinginkan seperti cenderung terjadi kesalahan kerja, kurang produktif, dan munculnya biaya-biaya pengeluaran tambahan untuk menanggulangi akibat gangguan yang terjadi (Helander, 2006).

Permasalahan yang sering terjadi pada petani stroberi adalah keluhan seperti sakit di leher, lengan, punggung, pinggang, dan merasa cepat lelah. Keluhan seperti ini dikenal sebagai keluhan subjektif yang terbagi dalam dua kategori yaitu keluhan otot skeletal dan kelelahan secara umum. Keluhan yang lain adalah lambatnya pembuatan lubang pada plastik mulsa. Untuk itu perlu dilakukan langkah-langkah solutif untuk membantu petani tersebut. Untuk membuat langkah solutif, maka terlebih dahulu dilakukan penelitian untuk mengkaji seberapa besar beban kerja yang ada pada petani stroberi tersebut, apakah beban kerja tersebut hanya dipengaruhi oleh pelaksanaan tugas petani (task) atau dipengarughi oleh lingkungan kerjanya (suhu, kelembaban, dan sebagainya). Oleh karena itu dilakukanlah penelitian ini, sebagai penelitian pendahuluan dalam memberikan langkah solutif bagi petani stroberi.

\section{Materi dan Metode}

Penelitian ini merupakan penelitian yang dilakukan secara observasional terhadap 12 orang petani stroberi di Kabupaten Tabanan. Beban kerja ditentukan dari nadi kerja yang dihitung dengan metode 10 denyut pada arteri radialis dengan stop watch. Suhu lingkungan dan kelembaban diukur dengan sling Psychrometer. Kecepatan angin diukur menggunakan Anemometer. Suhu panas radiasi matahari diukur dengan termometer bola. Keluhan subyektif di prediksi dari koesioner 30 item kelelahan dengan empat skala Likert, dan keluhan otot skeletal diprediksi dengan kosioner Nordic Body Map. ECPT (extra calorie due to peripheral temperature) dan ECPM (extra calorie due to peripheral metabolism) dihitung berdasarkan denyut nadi pemulihan petani. Analisa secara statistik dilakukan secara deskriptif terhadap beban kerja, keluhan-keluhan otot skeletal, keluhan subyektif, ECPT, dan ECPM.

\section{Hasil dan Pembahasan}

\subsection{Hasil}

Karakteristik petani stroberi yang menjadi subjek penelitian adalah sebagai berikut :

Tabel 1 Karakteristik subjek penelitian

\begin{tabular}{|c|c|c|c|c|}
\hline No & Variabel & $\begin{array}{c}\text { Rera } \\
\text { ta }\end{array}$ & $\begin{array}{l}\text { Simpan } \\
\text { g Baku }\end{array}$ & $\begin{array}{c}\text { Rentan } \\
\text { gan }\end{array}$ \\
\hline 1 & Umur (th) & $\begin{array}{c}35,1 \\
2\end{array}$ & 3,76 & $31-40$ \\
\hline 2 & $\begin{array}{l}\text { Berat } \\
\text { badan } \\
\text { (kg) }\end{array}$ & $\begin{array}{c}60,1 \\
1\end{array}$ & 3,14 & $\begin{array}{c}58,31- \\
64,82\end{array}$ \\
\hline 3 & $\begin{array}{l}\text { Tinggi } \\
\text { badan } \\
(\mathrm{cm})\end{array}$ & $\begin{array}{c}165, \\
51\end{array}$ & 4,32 & $\begin{array}{c}157,5- \\
170,5\end{array}$ \\
\hline 4 & $\begin{array}{l}\text { Indeks } \\
\text { Masa } \\
\text { Tubuh }\end{array}$ & $\begin{array}{c}21,5 \\
1\end{array}$ & 1,15 & $\begin{array}{c}20,06- \\
22,21\end{array}$ \\
\hline
\end{tabular}


ISSN Print : 1411 - 951 X, ISSN Online : 20503-1716

Jurnal Ergonomi Indonesia

(The Indonesian Journal of Ergonomic)

5 Pengalam

an kerja $\quad 5,17 \quad 2,26 \quad 3-9$

(th)

Hasil pengukuran mikroklimat di tempat kerja para petani stroberi yang

Hasil penghitungan denyut nadi kerja terhadap petani stroberi di Kabupaten

Tabel 3 Hasil penghitungan denyut nadi petani

\begin{tabular}{|c|c|c|c|c|}
\hline \multicolumn{5}{|c|}{ Stroberi } \\
\hline Variabel & $\begin{array}{l}\text { Mean } \\
(\mathrm{dpm})\end{array}$ & SD & $\mathrm{t}$ & $\mathrm{P}$ \\
\hline $\begin{array}{l}\text { Denyut } \\
\text { Nadi } \\
\text { Istirahat }\end{array}$ & $\begin{array}{c}71,1 \\
2\end{array}$ & 4,28 & \multirow{2}{*}{$-33,043$} & \multirow{2}{*}{$\begin{array}{c}0,00 \\
0\end{array}$} \\
\hline $\begin{array}{l}\text { Denyut } \\
\text { Nadi } \\
\text { Kerja }\end{array}$ & $\begin{array}{c}125 \\
22\end{array}$ & 2,94 & & \\
\hline
\end{tabular}

Keterangan : dpm $=$ denyut permenit

Beban kerja bisa dipengaruhi oleh faktor fisik atau internal tubuh (seperti gerak dan metabolisme) maupun faktor
Tabel 2. Kondisi lingkungan kerja

\begin{tabular}{llccc}
\hline No & Variabel & Rerata & $\begin{array}{c}\text { Simpang } \\
\text { Baku }\end{array}$ & Rentangan \\
\hline 1 & Suhu basah & 27,05 & 1,74 & $23,81-$ \\
& $\left({ }^{\circ} \mathrm{C}\right)$ & & & 29,22 \\
2 & Suhu kering & 31,66 & 2,22 & $27,11-$ \\
& $\left({ }^{\circ} \mathrm{C}\right)$ & & & 33,92 \\
3 & Kelembaban & 70,67 & 4,91 & $63,45-$ \\
& relatif $(\%)$ & & & 75,59 \\
4 & Suhu bola & 25,67 & 1,62 & $22,54-$ \\
& $\left({ }^{\circ} \mathrm{C}\right)$ & & & 25,04 \\
5 & WBGT $\left({ }^{\circ} \mathrm{C}\right)$ & 27,85 & 1,89 & $23,19-$ \\
& & & & 28,02 \\
\hline
\end{tabular}

Tabanan sebelum dan sesudah bekerja disajikan pada tabel 3 berikut.

Berdasarkan perhitungan denyut nadi diperoleh pula nilai Cardio Vasculer Load (CVL) yaitu 48,16 $\pm 3,04 \%$.

Hasil perhitungan keluhan otot skeletal yang didata dengan kuesioner Nordic Body Map dan pengukuran kelelahan secara umum menggunakan 30 item kuesioner, disajikan pada tabel 4 berikut :

Tabel 4 Hasil Analisis Keluhan Otot Skeletal dan kelelahan secara umum

\begin{tabular}{|c|c|c|c|c|c|}
\hline & & $\begin{array}{c}\text { Rerata } \\
\text { skor }\end{array}$ & $\mathrm{SD}$ & $\mathrm{t}$ & $\mathrm{P}$ \\
\hline \multirow{2}{*}{$\begin{array}{l}\text { Keluhan } \\
\text { Otot }\end{array}$} & $\begin{array}{l}\text { Sebelum } \\
\text { kerja }\end{array}$ & 32,42 & 1,44 & \multirow{2}{*}{18,415} & \multirow{2}{*}{0,000} \\
\hline & $\begin{array}{l}\text { Setelah } \\
\text { kerja }\end{array}$ & 69,19 & 6,32 & & \\
\hline \multirow{2}{*}{$\begin{array}{l}\text { Kelelahan } \\
\text { Secara } \\
\text { Umum }\end{array}$} & $\begin{array}{l}\text { Sebelum } \\
\text { kerja }\end{array}$ & 34,54 & 1,32 & \multirow{2}{*}{43,139} & \multirow{2}{*}{0,000} \\
\hline & $\begin{array}{l}\text { Setelah } \\
\text { kerja }\end{array}$ & 79,83 & 3,45 & & \\
\hline
\end{tabular}

eksternal tubuh pekerja (lingkungan kerja seperti panas matahari atau lingkungan yang dingin). Temperatur tinggi atau terik 
matahari bisa memberi pengaruh yang besar terhadap peningkatan beban kerja. Hasil analisis pengaruh kerja fisik dan pengaruh lingkungan kerja dapat di ukur menggunkan ECPT (extra cardiac pulse

Dengan menggunakan analisis RULA (Rapid Upper Limb Assessment),

Tabel 6. Hasil Skor Analisis RULA

\begin{tabular}{lccc}
\hline $\begin{array}{c}\text { Body Group A Postur } \\
\text { Rating }\end{array}$ & \multicolumn{2}{c}{$\begin{array}{c}\text { Body Group B } \\
\text { Postur Rating }\end{array}$} \\
\hline Upper Arm & $: 5$ & Neck & $: 1$ \\
Lower Arm & $: 3$ & & $: 5$ \\
& & Trunk & \\
Wrist & $: 2$ & \\
Twist & $: 1$ & Total $\quad: 6$ \\
Total & $: 6$ & \multicolumn{3}{c}{ Grand Score : 7 } \\
\hline \multicolumn{3}{c}{ Action : Investigation and changes are } \\
\multicolumn{3}{c}{ required immediatelly } \\
\hline
\end{tabular}

\subsection{Pembahasan}

Subjek dalam penelitian ini adalah petani stroberi dengan karakteristik sebagaimana tertera pada Tabel 1. Rentang umur petani adalah antara 31 hingga 40 tahun. Usia ini tergolong produktif dalam bekerja. Berat badan berada pada rentang 58,31 - 64,82 $\mathrm{Kg}$ dengan tinggi badan pada rentangn $157,5-170,5 \mathrm{~cm}$, sehingga mendapatkan indeks masa tubuh antara 20,06 - 22,21. Indeks ini tergolong normal, tidak kurus dan tidak gemuk. Pengalaman kerja petani stroberi pada rentang 3-9 tahun, bisa dinyatakan bahwa petani ini sudah berpengalaman dalam menanam stroberi.

Karakteristik subjek ini berpengaruh pada aktivitas pekerjaan. Kroemer and Grandjean (2009), menyatakan bahwa puncak kekuatan otot untuk laki-laki maupun wanita dicapai antara umur 25 sampai 35 tahun, due to temperature) dan ECPM (extra cardiac pulse due to metabolism). Hasil pengukuran ECPT dan ECPM disajikan pada Tabel 5 berikut.

Tabel 5. Hasil Analisis ECPT dan ECPM

\begin{tabular}{ccccc}
\hline & Rerata & SD & t & P \\
\cline { 1 - 3 } ECPT (dpm) & 29,43 & 4,31 & \multirow{2}{*}{$-2,324$} & \multirow{2}{*}{0,041} \\
\hline ECPM (dpm) & 31,24 & 4,62 & & \\
\hline
\end{tabular}

diperoleh hasil skor sebagaimana tertera pada Tabel 6 berikut.

performansi sebesar $96 \%$ dalam beraktivitas pada umur 40 tahun. Hasil penelitian yang dilakukan oleh Choobineh, et al (2007) menunjukkan bahwa seseorang yang memiliki indeks masa tubuh abnormal berisiko mengalami keluhan muskuloskeletal di daerah punggung bawah dua kali lebih tinggi dari pada orang dengan indeks masa tubuh normal. Sedangkan Rukka et al (2006) menyebutkan bahwa semakin lama pengalaman berusaha tani, maka tingkat respon terhadap suatu teknologi pertanian akan semakin tinggi. Oleh karena itu karakteristik petani akan berpengaruh pada penyelesaian pekerjaan, tingkat ketrampilan dan produktivitas kerjanya.

Kondisi lingkungan kerja pada petani stroberi di Kabupaten Tabanan sebagaimana tertera pada Tabel 2 masih tergolong normal. Walaupun Bedugul adalah daerah dingin, akan tetapi komponen kondisi lingkungan seperti suhu basah, suhu kering, kelembaban, suhu bola radiasi, dan WBGT masih tergolong pada nilai-nilai adaptasi normal pada tubuh petani. terlebih lagi petani stroberi yang sudah lama tinggal di daerah Bedugul Tabanan tersebut sudah mampu beradaptasi dengan baik dengan kondisi lingkungan tersebut.

Pada pengukuran kondisi lingkungan kerja diperoleh suhu basah $27,05{ }^{\circ} \mathrm{C}$, Suhu kering $31,66{ }^{\circ} \mathrm{C}$, dengan kelembaban 70,67\%. Kondisi ini tergolong 
nyaman bagi petani stroberi dalam bekerja. Manuaba (1998) menyatakan bahwa nilai ambang batas dari suhu udara untuk pekerja adalah $33^{\circ} \mathrm{C}$ dan kelembaban relatif pekerja orang Indonesia yang masih tergolong nyaman adalah antara $60 \%$ $80 \%$.

Beban kerja seseorang bisa diukur berdasarkan denyut nadi (Adiputra, 2002). Berdasarkan perhitungan denyut nadi kerja sebagaimana tertera pada Tabel 3, diperoleh bahwa denyut nadi istirahat adalah 71,12 denyut permenit, sedangkan denyut nadi kejra adalah 125,22 denyut permenit. Terdapat peningkatan yang signifikan $(p<0,005)$ antara denyut nadi istirahat dengan denyut nadi kerjanya. Pada denyut nadi kerja tersebut tergolong beban kerja berat. Kroemer dan Grandjean

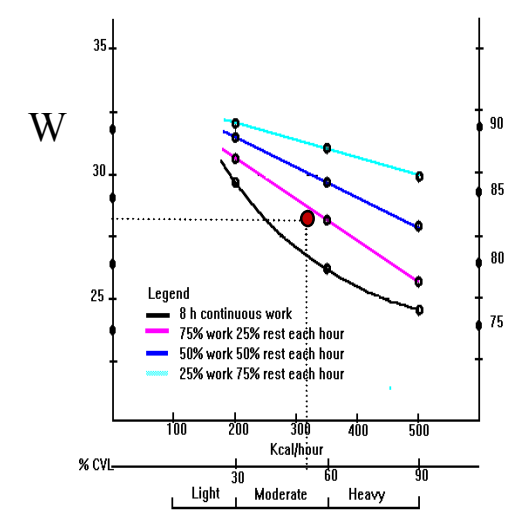

Gambar 1. Grafik waktu kerja dan istirahat berdasarkan ISBB dan \% CVL

Berdasar grafik pada Gambar 1 di atas, dapat dilihat bahwa dengan \%CVL dan nilai WBGT yang diperoleh dari petani stroberi di Kabupaten Tabanan, seharusnya mereka bekerja dengan pembagian $75 \%$ kerja dan $25 \%$ istirahat. Agar petani bisa bekerja secara terus menerus 8 jam kerja maka perlu ada perbaikan pada sistem kerjanya sehingga bisa menurunkan nilai \%CVL.

Keluhan subjektif petani sebagaimana tertera pada Tabel 4 , terjadi peningkatan yang signifikan $(p<0,05)$ antara pengukuran sebelum kerja dan
(2009) menyatakan denyut nadi kerja tergolong berat pada rentang $125-130$ denyut permenit.

Jika nilai denyut nadi kerja dikombinasikan dengan nilai denyut nadi istirahat dan umur petani akan diperoleh nilai cardio vasculer load (CVL). Dari hasil perhitungan, nilai \%CVL petani stroberi di Kabupaten Tabanan ini diperoleh 49,26 $\pm 2,27 \%$. Menurut Intaranont danVanwonterghem (1993) nilai \%CVL tersebut termasuk beban kerja sedang dan perlu perbaikan (attention level, improvement measurement advised). Kombinasi nilai CVL tersebut dan nilai WBGT sebagaimana tertera pada Tabel 2 maka akan diperoleh rekomendasi durasi waktu kerja dan durasi waktu istirahat sebagaimana grafik Gambar 1 berikut.

setelah kerja baik pada keluhan otot skeletal maupun pada kelelahan secara umum. Setelah kerja keluhan otot skeletal yang terjadi pada petani stroberi terjadi sakit di bahu, leher, dan pinggang $(100 \%$ petani), sakit di lengan kiri, lengan kanan, serta sakit di punggung ( $80 \%$ dari petani). Sedangkan kelelahan secara umum yang terjadi yaitu lelah pada seluruh badan, nyeri di punggung dan merasa haus $(100 \%$ dari petani), kemudian juga merasa berat di kepala, kaki terasa berat, kaku atau canggung dalam bergerak, kaku dibagian bahu, dan badan terasa gemetar diperoleh $80 \%$ dari pekerja. Apabila hal keluhankeluhan ini tidak diberikan solusi dengan baik dan petani terus menerus mendapatkan keluhan tersebut, maka akan berakibat buruk dari sisi kesehatan petani.

Keluhan ini terjadi karena sikap kerja petani stroberi yang berdiri membungkuk. Sikap kerja membungkuk dalam waktu yang lama adalah sikap kerja yang tidak fisiologis. Sikap kerja yang 
tidak fisiologis dapat diakibatkan oleh karakteristik tuntutan tugas, alat kerja, stasiun kerja, dan sikap kerja yang tidak sesuai dengan kemampuan dan keterbatasan pekerja (Manuaba, 2000). Sikap kerja tidak fisiologis yang dilakukan selama bertahun-tahun dapat menyebabkan kelainan tulang pada pekerjanya (Kroemer and Grandjean, 2009). Untuk mengatasi hal ini perlu adanya perbaikan sikap kerja dengan cara membuat alat baru atau sistem kerja baru dengan mengikuti kaedah ergonomi.

Berdasarkan nilai ECPT dan ECPM seperti pada Tabel 5 diperoleh bahwa nilai ECPT berbeda signifikan dengan nilai ECPM, dan nilai ECPT lebih besar daripada nilai ECPM. Menurut Adiputra (2002) apabila:

a) Nilai ECPT > ECPM, berarti bahwa faktor lingkungan lebih dominan sehingga memberikan beban kerja tambahan kepada subjek. Dalam upaya perbaikan maka aspek lingkungan itu harus ditekan sekecil mungkin.

b) Nilai ECPM > ECPT, berarti bahwa kerja fisik tugas yang dilakukan memang berat. Upaya intervensinya ditujukan untuk menurunkan beban kerja utama.

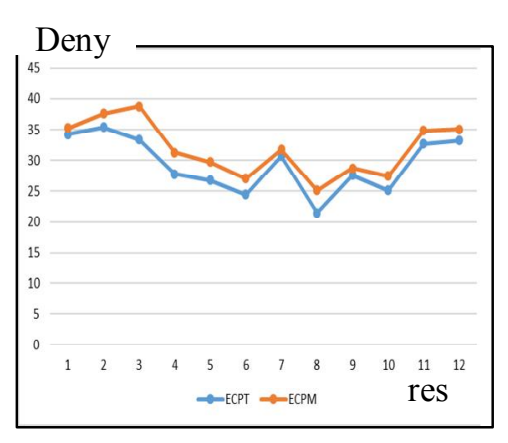

Dengan menggunakan analisis RULA dengan pada kerja sebagaimana tertera pada Gambar 3 di atas dan nilai skor pada analisis RULA yang tertera pada Table 6 , diperoleh total skor 6 baik pada bagian tubuh grup A maupun pada bagian c) Nilai ECPM = ECPT, itu berarti bahwa beban fisik pekerjaan dan aspek lingkungan sama-sama memberikan beban kepada tubuh; dengan demikian upaya intervensi ditujukan kepada keduanya.

Dari hasil perhitungan diperoleh ECPM lebih besar dari ECPT, hal ini menunjukkan bahwa faktor kerja fisik lebih dominan terhadap petani dibandingkan dengan pengaruh suhu lingkungan kerjanya. Sistem kerja pengolahan media tanam stroberi dalam membuat bedeng, memasang plasik mulsa, dan membuat lubang pada plastik mulsa tersebut adalah pekerjaan dengan beban kerja berat dan perlu adanya intervensi segera. Hal ini juga menunjukkan bahwa jika ingin membuat intervensi untuk memperbaiki pelaksanaan aktivitas pekerjaan petani maka intevensi tersebut diarahkan pada hal-hal yang berhubungan dengan faktor kerja fisik seperti memperbaiki peralatan kerja dan sistem kerjanya.

Perbedaan antara ECPM dan ECPT secara grafis ditunjukkan dalam Gambar 2. Terlihat bahwa ECPM secara signifikan lebih besar daripada ECPT $(\mathrm{p}<0,05)$.

Gambar 2. Grafik nilai ECPT dan ECPM
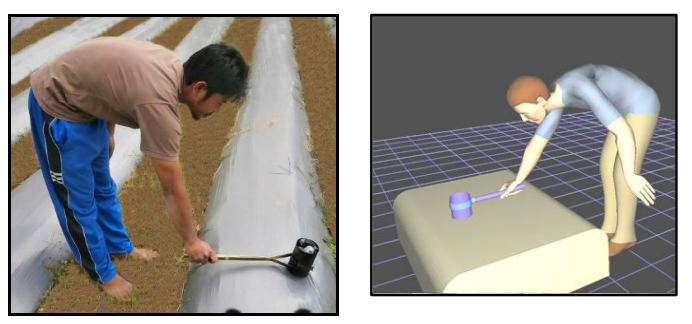

Gambar 3 Sikap kerja melubangi plastik mulsa

tubuh grup B, dan grand score 7 dengan rekomendasi aksi adalah segera dilakukan perbaikan.

Oleh karena itu, dari hasil analisis beban kerja petani stoberi di Kabupaten Tabanan ini di rekomendasikan untuk 
segera dilakukan perbaikan baik pada sikap kerja nya maupun pada peralatan kerjanya.

\section{SIMPULAN DAN SARAN. \\ 4.1 Simpulan}

Dari hasil analisis dan pembahasan di atas, dapat diambil kesimpulan sebagai berikut.

1. Beban kerja petani stroberi di Kabupaten Tabanan termasuk dalam kategori beban kerja yang berat.

2. Terdapat perbedaan yang signifikan pada skor keluhan subjektif petani (keluhan otot skeletal dan kelelahan secara umum) sebelum dan sesudah kerja. Setelah kerja keluhan otot skeletal yang terjadi pada petani stroberi terjadi sakit di bahu, leher, dan pinggang (100\% petani), sakit di lengan kiri, lengan kanan, serta sakit di punggung ( $80 \%$ dari petani). Sedangkan kelelahan secara umum yang terjadi yaitu lelah pada seluruh badan, nyeri di punggung dan merasa haus (100\% dari petani), kemudian juga merasa berat di kepala, kaki terasa berat, kaku atau canggung dalam bergerak, kaku dibagian bahu, dan badan terasa gemetar diperoleh $80 \%$ dari pekerja.

3. Nilai ECPM lebih besar dari ECPT sehingga upaya-upaya untuk memperbaiki pelaksanaan aktivitas petani stroberi dapat diarahkan pada hal-hal yang berhubungan dengan pelaksanaan kerja seperti memperbaiki peralatan kerja dan sistem kerjanya.

4. Skor analisis rula diperoleh nilai grand score 7, hal ini direkomendasikan untuk segera dilakukan perbaikan pada pelaksanaan kerja petani stroberi.

\section{2 $\mathrm{S}$ a r a n.}

Beberapa hal yang bisa disarankan untuk para petani stroberi antara lain adalah.

1. Memperbaiki peralatan kerja sehingga sikap kerja tidak membungkuk lagi (sikap kerja alamiah) dan pembuatan lubang pada plastik mulsa bisa dilakukan lebih cepat.
2. Mengatur sistem kerjanya seperti mengatur jam kerja, mengatur istirahat kerja dengan cara memberikan istirahat pendek 5 sampai 10 menit setiap jam kerja, pemberian air minum dan semacamnya.

3. Perlu ada penelitian lebih lanjut tentang perbaikan sistem kerja petani stroberi tersebut.

\section{DAFTAR PUSTAKA}

Adiputra, N. 2002. Denyut Nadi dan Kegunaannya dalam Ergonomi. Jurnal Ergonomi Indonesia, Vol. 3, No. 1, Juni 2002: 22-26.

Arimbawa, I Wayan Buda Parmadi. 2012. Sejarah Pembudidayaan Tanaman Strawberry di Desa Candikuning, Baturiti, Tabanan-Bali (1986-2012). e-journal Undhiksa. terdapat pada http://ejournal.undiksha.ac.id/index.p $\mathrm{hp} / \mathrm{JCS} /$ article/view/292/247 diakses pada tanggal 1 Juni 2016.

Budiman dan Sastrawati. 2008. Berkebun Stroberi secara komersial. Depok : Penebar Swadaya.

Choobineh A, Tabatabaei, Sayed H, Mokhtarzadeh A, Salehi M. 2007. Musculoskeletal Problems among Workers of an IranianRubber Factory: Journal of Occupational Health 2007;49:48-423.

Helander, M. 2006. A guide to The Ergonomics of Manufacturing. Second edition. CRC Press. New york : Taylor and Francis group.

Hui YH. 2006. Handbook of Fruit and Fruit Processing. Blackwell Publishing.

Intaranont, K. dan Vanwonterghem, K. 1993. Study of Exposure Limit in Contraining Climatic Conditions for Strenous Task : an Ergonomic Aproach. Final Report. Bangkok : Chulangkom University Department of Industrial Engeneering. 
ISSN Print : 1411 - $951 \mathrm{X}$, ISSN Online : 20503-1716

Jurnal Ergonomi Indonesia

(The Indonesian Journal of Ergonomic)

Kroemer, K.H.E., and Grandjean, E. 2009. Fiting the Task to the Human, Textbook of Occupational Ergonomics, Fifth Edition. Taylor \& Francis Inc. London.

Manuaba, A. 2000. Research and Application of Ergonomics in Developing Countries, with Special Reference to Indonesia. Jurnal Ergonomi Indonesia. 1(1-6): 24-30.

Manuaba, A.1998. Bunga Rampai Ergonomi vol.1. Program Studi Ergonomi-Fisiologi Kerja Universitas Udaayana Denpasar.

Monografi Desa Candikuning II. 2011. Desa Candikuning II, Kecamatan Baturiti, Kabupaten Tabanan.

Rukka H., Buhaerah, Sunaryo. 2006. Hubungan Karakteristik Petani dengan Respon Petani terhadap Penggunaan Pupuk Organik pada Padi sawah (Oryza sativa L.). Jurnal Agrisistem, Juni 2006, Vol 2 No. 1. Hal: $12-18$. 